Parnell GP, Shahijanian F, Coulter S, Schibeci SD, et al. Genes Immun 2016;17(4):213-9.

[2]

[2] Serum vitamin $D$ and colonic vitamin $D$ receptor in inflammatory bowel disease. Abreu-Delgado Y, Isidro RA, Torres EA, González A, Cruz ML, Isidro AA, et al. World J Gastroenterol 2016;22(13):3581-91.

[1] Cistromic and genetic evidence that the vitamin $D$ receptor mediates susceptibility to latitude-dependent autoimmune diseases. Booth DR, Ding N, Parnell GP, Shahijanian F, Coulter S, Schibeci SD, et al. Genes Immun 2016;17(4):213-9.

[2] Serum vitamin $D$ and colonic vitamin $D$ receptor in inflammatory bowel disease. Abreu-Delgado Y, Isidro RA, Torres EA, González A, Cruz ML, Isidro AA, et al. World J Gastroenterol 2016;22(13):3581-91.

Disclosure of Interest: None declared

DOI: 10.1136/annrheumdis-2018-eular.6890

\section{AB0854 DYSFUNCTIONAL PAIN COMPONENT IN ANKYLOSING SPONDYLITIS PATIENTS}

E. Filatova, S. Erdes. V.A. Nasonova Research Institute of Rheumatology, Moscow, Russia, Moscow, Russian Federation

Background: As a result of chronic inflammation, repetitive activation of primary afferent fibres changes the functional state and activity of Central nervous pathways. On this patients when describing their complaints use neuropathic pain descriptors include numbness, burning, tingling, increased pain response to a stimulus nabulivou etc.

Objectives: The study of chronic pain syndrome in patients with ankylosing spondylitis (AS) to identify dysfunctional component of pain (DCP).

Methods: Was studied 150 patients as 127 men and 23 women. The average age of 35 , and $52 \pm 10,55$, mean disease duration of $7.19 \pm$ of 6.31 . All the patients were performed clinical and rheumatological examination (indices BASDAI, BASFI), the assessment of pain intensity on visual analogue scale (VAS), to identify DCP were investigated neurological status with the use of questionnaires neuropathic pain DN4 and PainDETECT, and identifying the emotional-affective disorders (HADS questionnaire).

Results: 22 patients (14.7\%) on the DN4 questionnaire revealed 4 or more points, but lesions of the somatosensory nervous system in these patients was not detected, hence $14,7 \%$ of patients were identified DCP. When comparing patients with the presence of TCS group I (22 people) and no DCP group II (128) it has been found that statistically significantly in patients in group I had higher pain intensity on VAS $(6,09 \pm 185$ vs $4,55 \pm 2,06, p=0.001$, respectively); active disease BASDAl index (of $7.05 \pm v s 1,584,87 \pm 2,16, p=0.001$, respectively); the expression of functional impairment index BASFI $(6,46 \pm 2,24$ vs $4,05 \pm 2,81, p=0.001)$; the indicators of the questionnaire HADS in group I, consistent with the presence of clinically significant anxiety and lack of it in group II $(10,09 \pm 2,86$ vs $6,17 \pm 3,35$, $\mathrm{p}=0.0001)$. However, duration of disease distinguish authentic in the groups was not $(9,41 \pm 6,896,81$ vs $\pm 6,13 p=0,07)$. Correlation analysis revealed a significant relationship between DCP and the intensity of the pain in VAS back, as well as with the severity of anxiety, disease activity, functional disorders $(p=0.05)$

Conclusions: The study identified 22 patients, the presence of neuropathic pain descriptors in combination with anxiety disorders, resulting in the conclusion that, along with nociceptive component of pain in $14.7 \%$ of cases detected by the DCT. So the pain of some AS patients should be considered as a multicomponent syndrome, providing a comprehensive approach with the use of antidepressants (TCA and SSRI's).

Disclosure of Interest: None declared

DOI: 10.1136/annrheumdis-2018-eular.2312

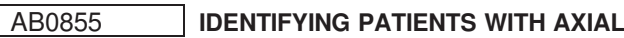 SPONDYLOARTHRITIS BY DATA MINING MRI RADIOLOGY REPORTS}

E. Reilly, A. Szachowicz, R. Sengupta. Royal National Hospital for Rheumatic Diseases, Bath, UK

Background: Axial Spondyloarthritis (axSpA) encompasses ankylosing spondylitis (AS) and non radiographic axSpA (nr-axSpA) as part of the ASAS classification criteria ${ }^{12}$. The role of MRI is now central in identifying patients early in the disease course ${ }^{3}$, but our use of this needs to be standardised to ensure appropriate requesting and correct interpretation of $\mathrm{MRI}$ axSpA features.

Objectives: ( ${ }^{1}$ To identify the MRI protocols used to investigate patients with back pain

( ${ }^{2}$ To describe the prevalence of axSpA associated spinal lesions in patients with known axSpA
( ${ }^{3}$ To describe the prevalence of axSpA associated spinal lesions in patients with back pain and their relevance in subsequently diagnosed axSpA

Methods: MRI reports between 4th January 2015 and 25th February 2017 contain ing the key words 'ankylosing spondylitis' (AS), 'bone marrow oedema' (BMO), 'spondyloarthritis' and 'sacroiliitis' were identified using a computerised word finding programme, in a tertiary referral hospital for Rheumatology.

Results: 194 patients had MRI features of axSpA. $60.8 \%$ were female; mean age 39.3 years (SD 13.3). $96.4 \%(n=187)$ contained the term 'sacroiliitis', with 'AS 'BMO' and 'spondyloarthritis' in $2.6 \%, 0.5 \%$ and $0.5 \%$ respectively. $63.4 \%$ were referred by a rheumatologist, and $19.1 \%$ from primary care. Musculoskeletal radiologists reported $16.0 \%$, general radiologists $37.1 \%$, and external radiology services $46.4 \%$. The most common MRI protocol was the inflammatory spinal protoco (ISP-MRI, 57.2\%), with sacroiliac (SIJ) MRI in 17\%. 87.4\% ISP-MRI and $48.5 \%$ MRI SIJ were requested by Rheumatology. GPs requested more ISP-MRI than other sequences ( $29.7 \%$ of their total MRIs). 144 cases had a diagnosis stated on the $\mathrm{MRI}$ request; 100 (69.4\%) had an existing diagnosis of axSpA, and 20 (13.9\%) of a peripheral arthritis. In patients with known $\mathrm{AxSpA}$, the most frequent findings were BMO (70.3\%), and erosions (67\%). Ankylosis was only seen in 4 patients. Features of axSpA were identified in $26 \mathrm{MRls}$ requested for mechanical back pain, and 11 for unrelated medical reasons. 33 cases of BMO and 29 of SIJ erosions were identified in patients who did not have a pre existing diagnosis of AxSpA, and one showed ankylosis. 16 patients went on to have a diagnosis of $\operatorname{axSpA}$.

Abstract AB0855 - Table 1. Radiological features seen on MRI imaging, and by diagnosis

\begin{tabular}{|c|c|c|c|c|c|}
\hline \multirow[t]{2}{*}{ MRI finding } & \multirow{2}{*}{$\begin{array}{l}\text { Frequency } \\
n(\%)\end{array}$} & \multirow{2}{*}{$\begin{array}{l}\text { Pre existing } \\
\text { axSpA } \\
\text { diagnosis, } \\
n(\%)\end{array}$} & \multicolumn{3}{|c|}{$\begin{array}{l}\text { Without pre existing axSpA diagnosis, } \\
\text { Total } n=44\end{array}$} \\
\hline & & & $\begin{array}{l}\text { peripheral } \\
\text { arthritis, } \\
\mathrm{n}(\%)\end{array}$ & $\begin{array}{l}\text { back pain as yet } \\
\text { undiagnosed, } \\
\mathrm{n}(\%)\end{array}$ & $\begin{array}{l}\text { alternative } \\
\text { diagnosis, } \\
\mathrm{n}(\%)\end{array}$ \\
\hline Totaln & 194 & 100 & 20 & 13 & 11 \\
\hline Oedema & $150(77.3)$ & $78(70.3)$ & $15(13.5)$ & $8(7.2)$ & $10(9.0)$ \\
\hline $\begin{array}{l}\text { Irregularity or } \\
\text { erosions }\end{array}$ & $111(57.2)$ & $59(67.0)$ & $16(18.2)$ & $6(6.8)$ & $7(8.0)$ \\
\hline $\begin{array}{l}\text { Sub-articular } \\
\text { sclerosis }\end{array}$ & $81(41.8)$ & $39(63.9)$ & $13(21.3)$ & $4(6.6)$ & $5(8.2)$ \\
\hline $\begin{array}{l}\text { Fatty } \\
\text { infiltration }\end{array}$ & $29(14.9)$ & $18(75.0)$ & $5(20.8)$ & 0 & $1(4.2)$ \\
\hline $\begin{array}{l}\text { Corner } \\
\text { inflammatory } \\
\text { spinal lesions }\end{array}$ & $30(15.5)$ & $18(69.2)$ & $4(15.4)$ & $2(7.7)$ & $2(7.7)$ \\
\hline Ankylosis & $5(2.6)$ & $4(80.0)$ & 0 & $1(20.0)$ & 0 \\
\hline Fracture & $4(2.1)$ & $4(100)$ & 0 & 0 & 0 \\
\hline \multirow{4}{*}{$\begin{array}{l}\text { Post MRI } \\
\text { diagnosis: }\end{array}$} & & $\operatorname{axSpA}, n(\%)$ & \multicolumn{3}{|c|}{$16(36.4)$} \\
\hline & \multicolumn{2}{|c|}{ Mechanical, n(\%) } & \multicolumn{3}{|c|}{$8(18.2)$} \\
\hline & \multicolumn{2}{|c|}{$\begin{array}{r}\text { Seroneg ative arthritis, } \\
\mathrm{n}(\%)\end{array}$} & \multicolumn{3}{|c|}{$8(18.2)$} \\
\hline & \multicolumn{2}{|c|}{$\begin{array}{r}\text { Isolated sacroilitis } \\
\text { (without full criteria for } \\
\text { axSpA), } \mathrm{n}(\%)\end{array}$} & \multicolumn{3}{|c|}{$7(15.9)$} \\
\hline
\end{tabular}

Conclusions: Through data mining of MRI reports, we have found that appropriate $\mathrm{MRI}$ sequences are being requested when features of $\mathrm{AxSpA}$ are suspected. The rate of chronic features of $\mathrm{AxSpA}$ such as ankylosis was low, suggesting this cohort may have short disease durations. Multiple features of AxSpA were identified in patients without an existing diagnosis prior to imaging. 16 new cases of AxSpA were identified.

\section{REFERENCES :}

[1] Rudwaleit M, van der Heijde D, Landewé R, et al, The development of assessment of spondyloarthritis international society classification criteria for axial spondyloarthritis (part II): validation and final selection. Ann Rheum Dis 2009; 68:77783.doi:10.1136/ard.2009.108233,

[2 Baraliakos X, Braun J]

Non-radiographic axial spondyloarthritis and ankylosing spondylitis: what are the similarities and differences? RMD Open 2015;1:e000053.doi:10.1136/ rmdopen-2015-000053

[] 3

Hoffstetter P et al, Magnetic Resonance Imaging of the Axial Skeleton in Patients With Spondyloarthritis: Distribution Pattern of Inflammatory and Structural Lesions, Clin Med Insights Arthritis Musculoskelet Disord. 2017; 10: 1179544117728081, Published online 2017 Aug 29.

Disclosure of Interest: None declared DOI: 10.1136/annrheumdis-2018-eular.588 